Article

\title{
Investigation on Oxidation Behavior of Super304H and HR3C Steel in High Temperature Steam from a 1000 MW Ultra-Supercritical Coal-Fired Boiler
}

\author{
Jingjing $\mathrm{Li}^{1,2}$, Haidong Ma ${ }^{2}$, Yungang Wang ${ }^{2, * \mathbb{D}}$, Min Xue ${ }^{2}$ and Qinxin Zhao ${ }^{2}$ \\ 1 Xi'an Special Equipment Inspection Institute, Xi'an 710065, China; lijingjing19710124@outlook.com \\ 2 Key Laboratory of Thermo-Fluid Science and Engineering of Ministry of Education, Xi'an Jiaotong \\ University, Xi'an 710049, China; mhd.19910220@stu.xjtu.edu.cn (H.M.); \\ xm3118303345@stu.xjtu.edu.cn (M.X.); zhaoqx@xjtu.edu.cn (Q.Z.) \\ * Correspondence: ygwang1986@xjtu.edu.cn; Tel.: +86-029-82667749
}

Received: 21 December 2018; Accepted: 2 February 2019; Published: 7 February 2019

\begin{abstract}
Oxidation behavior of Super304H and HR3C steel in high temperature steam from an ultra-supercritical coal-fired boiler was investigated in this paper. The results showed that the steam oxidized surface of Super304H ware composed of $\mathrm{Fe}_{2} \mathrm{O}_{3}, \mathrm{Cr}_{2} \mathrm{O}_{3}$ and $\mathrm{FeCr}_{2} \mathrm{O}_{4}$, the oxide scale had a thickness of 50-70 $\mu \mathrm{m}$. In addition, the steam oxidized surface of HR3C ware composed of $\mathrm{Fe}_{2} \mathrm{O}_{3}$, the oxide scale was about $20 \mu \mathrm{m}$ in thickness and contained few pitting. The oxidation product layer of the two samples could be divided into two layers, including outer layer enriched O element and Fe element, and inner layer enriched $\mathrm{O}$ element and $\mathrm{Cr}$ element. Furthermore, oxide scale spalling was observed on the surface of Super $304 \mathrm{H}$ sample.
\end{abstract}

Keywords: stainless steel; Super304H; HR3C; steam oxidation; ultra-supercritical boiler

\section{Introduction}

Increasing steam parameters (pressure and temperature) of utility boilers can effectively improve fossil energy utilization to reduce pollutant emissions [1,2]. The application of ultra-supercritical technology puts higher requirements on the steam oxidation resistance of high temperature heating surface materials $[3,4]$. The increase of steam temperature leads to an accelerated material oxidation rate, and the oxide scale will peel off as its thickness increases, as well as affect the component life and overall efficiency of the boiler [5-7]. There are few materials used in boiler with good high temperature oxidation resistance, steam oxidation resistance and mechanical property in the temperature range of 650-700 ${ }^{\circ} \mathrm{C}$ now. As main steam temperature in the ultra-supercritical boiler develops continuously to high parameter rapidly, metal wall temperature of super-heater and re-heater gradually approach or exceed $680^{\circ} \mathrm{C}$, which is in the second peak area of high temperature oxidation rate, the oxidation rate will increase greatly. Super304H $(0.1 \mathrm{C} 18 \mathrm{Cr} 9 \mathrm{Ni} 3 \mathrm{CuNbN})$ and $\mathrm{HR} 3 \mathrm{C}(25 \mathrm{Cr} 20 \mathrm{Ni} \mathrm{NbN})$ are two kinds of high temperature alloy steels that widely used $[8,9]$. Super304H has good endurance strength and high temperature steam oxidation resistance, $\mathrm{HR} 3 \mathrm{C}$ has better heat intensity property. Super $304 \mathrm{H}$ and HR3C have been widely used in the manufacture of superheater or reheater [10,11].

In the beginning researchers were concerned about steam oxidation of ferritic steel [12], then focused on the steam oxidation behavior of austenitic steel and achieved remarkable results. Wright and Pint investigated the oxidation behavior of austenitic steel and compared with various types of ferritic steel, and found that austenitic steel had better oxidation resistance because of the form of $\mathrm{Cr}_{2} \mathrm{O}_{3}$ protective layer that could delay oxidation rate [1,13]. Hansson and Montgomery analyzed the steam oxidation behavior of the TP347HFG samples from an ultra-supercritical utility boiler. 
They also compared the steam oxidation behavior of TP347HFG and TP347H, and then obtained the influence law of grain structure on the material steam oxidation resistance behavior [14]. Liang experimentally investigated the high temperature oxidation of the newly developed alloy 282 under the condition of flowing air and steam [15]. Also, the steam oxidation behavior of Super304H in simulating high temperature steam environment was studied in the laboratory [16]. Similarly, Yuan et al. investigated the steam oxidation resistance of Super304H after different surface treatments of grinding (1000 grit with $\mathrm{SiC}$ papers), polishing (1 $\mathrm{m}$ at last) and sandblasting, using an air-blast machine with $\mathrm{Al}_{2} \mathrm{O}_{3}-\mathrm{SiO}_{2}$ mixture beads at $0.2-0.4 \mathrm{MPa}$ [17]. The steam oxidation behavior of $\mathrm{HR} 3 \mathrm{C}$ was discussed, and compared with that of TP347H and high-entropy alloy $\mathrm{Al} \times \mathrm{CoCrFeNi}$, as the results showed. The oxidation resistance of shot peened TP304H was even better than shot peened HR3C [18]. The comparative analyses between Super304H and HR3C were carried out by Iseda, but Iseda mainly focused on the long-term creep properties and microscopic results [19]. Lukaszewicz conducted a series of studies on the steam oxidation behavior of various materials in the laboratory, in additional, he reported some results from an investigation into the impact of steam flow rates and sample orientation on the steam oxidation of surface ground superheater tube materials. [20-22]. However, there are few studies on the comparison of steam oxidation behavior of various austenitic steels in long-term service environment (over 15,000 h). In this paper, Super304H and HR3C steel tubes with service time of $17,973 \mathrm{~h}$ in a $1000 \mathrm{MW}$ ultra-supercritical coal-fired boiler were site cutting and analyzed by X-ray diffraction (XRD), scanning electron microscopy (SEM) and energy-dispersive spectrometry (EDS). The results can facilitate the understanding of the steam oxidation mechanism under the actual operating condition, and is useful to ensure the power plant boiler operate safely and efficiently for a long period of time.

\section{Experimental Samples and Methods}

The samples derived from super-heater and reheater in a $1000 \mathrm{MW}$ ultra-supercritical coal-fired boiler in China (Figure 1). Respectively, the steam pressure and temperature of the high-temperature super-heater is $26.15 \mathrm{MPa}$ and $605^{\circ} \mathrm{C}$. Furthermore, the experimental tubes accumulated operation 17,973 $\mathrm{h}$ and its composition were shown in Table 1. As described in Table 2, the material for superheater was Super304H, and the sample was selected from the outlet of the rear panel superheater (12th tube of the 30th screen from front to the back). For the reheater, the material was HR3C, and the sample was selected from first tube of the 20th row of the rear screen.

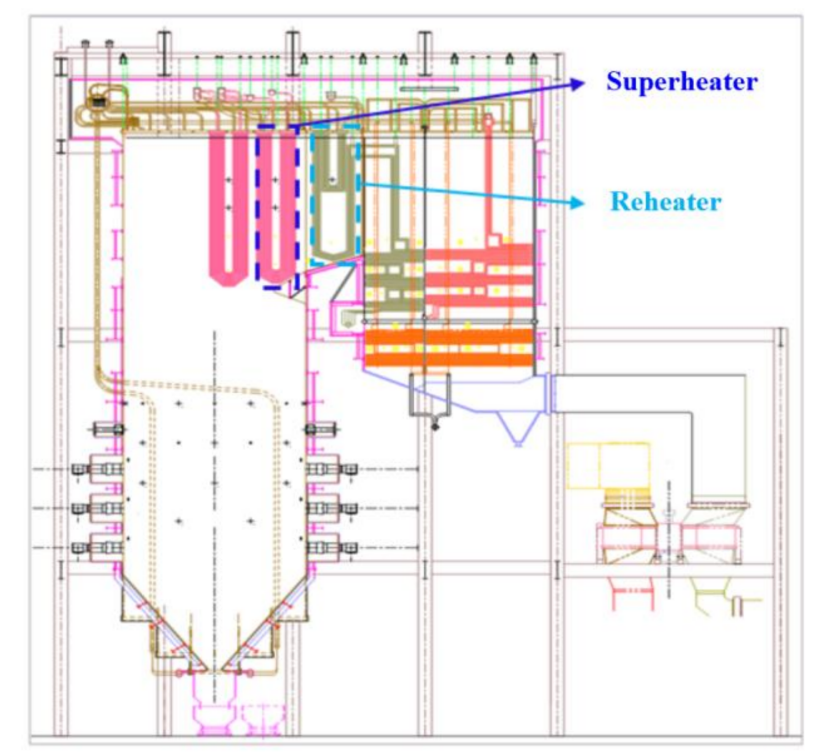

Figure 1. Tube exposed position in the boiler. 
Table 1. Compositions of Super304H and HR3C steels (wt\%).

\begin{tabular}{cccccccccccccc}
\hline Alloy & Fe & C & Si & Mn & P & S & Ni & $\mathbf{C r}$ & $\mathbf{V}$ & $\mathbf{B}$ & $\mathbf{N}$ & $\mathbf{C u}$ & $\mathbf{N b}$ \\
\hline Super304H & Bal. & 0.08 & 0.22 & 0.75 & 0.025 & 0.002 & 8.68 & 18.71 & $<0.1$ & $<0.0005$ & 0.09 & 2.97 & 0.48 \\
HR3C & Bal. & 0.06 & 0.42 & 1.13 & 0.012 & 0.002 & 19.56 & 25.61 & $<0.1$ & $<0.0005$ & 0.28 & - & 0.39 \\
\hline
\end{tabular}

Table 2. Operational parameters of Super304H and HR3C tubes.

\begin{tabular}{|c|c|c|c|c|c|c|}
\hline Material & Size (mm) & Component & Location & Elevation & $\begin{array}{c}\text { Temperature } \\
\left({ }^{\circ} \mathrm{C}\right)\end{array}$ & $\begin{array}{l}\text { Pressure } \\
(\mathrm{MPa})\end{array}$ \\
\hline Super304H & $\phi 51 \times 9$ & $\begin{array}{c}\text { rear panel } \\
\text { superheater }\end{array}$ & $30-12$ & $\begin{array}{l}\text { outlet section, four } \\
\text { meters from elbow }\end{array}$ & 580-607 & $25.98-26.17$ \\
\hline HR3C & $\phi 60 \times 4$ & $\begin{array}{l}\text { final-stage reheater } \\
\quad \text { (rear panel) }\end{array}$ & $20-1$ & $\begin{array}{l}\text { outlet section, six } \\
\text { meters from elbow }\end{array}$ & 590-617 & $7.05-7.25$ \\
\hline
\end{tabular}

For analysis convenience, the test tubes were cut to samples illustrated in Figure 2. First, phase analysis was conducted by using XRD with a PANalytical X'pert PRO MPD powder diffractometer (Netherlands). It is employed $\mathrm{Cu} \mathrm{K} \alpha$ radiation $(\lambda=0.15406 \mathrm{~nm})$ and operated at $40 \mathrm{~mA}$ and $40 \mathrm{kV}$, as well as recorded at a scan rate of $1^{\circ} / \mathrm{min}$ in the range of $20^{\circ}<2 \theta<80^{\circ}$. The JADE6.5 software package was employed to fulfill the peak identification comparing with standards. Then, samples were the poured with denture powder in advance to prevent the oxidation layer falling off during sample grinding and polishing. Finally, the samples were analyzed by utilizing the SEM and EDS with JSM-6390 (Japan) at the accelerating voltage of $15 \mathrm{kV}$.

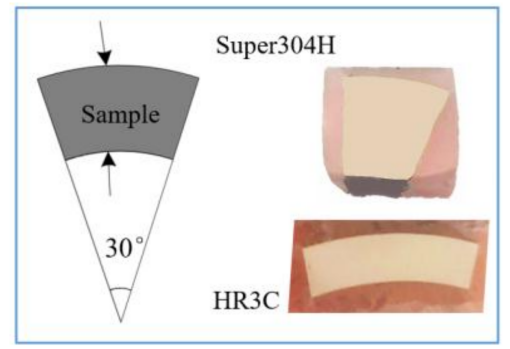

Figure 2. Schematic diagram of cutting samples.

\section{Experimental Results}

\subsection{Surface Analysis}

The XRD analysis results were shown in Figure 3 and Table 3. It can be seen that the steam oxidised surface of the Super $304 \mathrm{H}$ were mainly consist of $\mathrm{Fe}_{2} \mathrm{O}_{3}, \mathrm{Cr}_{2} \mathrm{O}_{3}$, and $\mathrm{FeCr}_{2} \mathrm{O}_{4}$ In contrast, the steam oxidised surface of the HR3C sample was only $\mathrm{Fe}_{2} \mathrm{O}_{3}$.

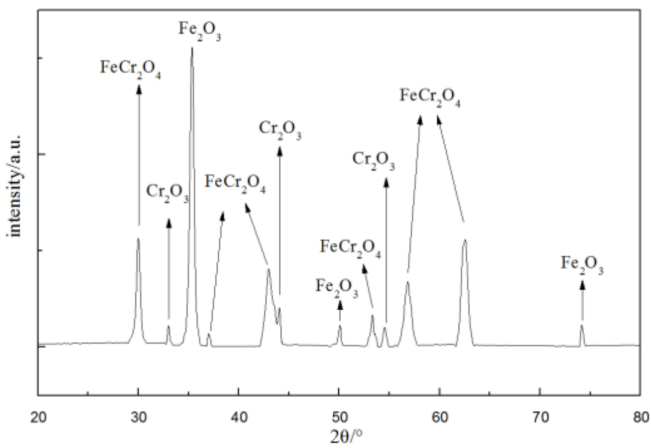

(a)

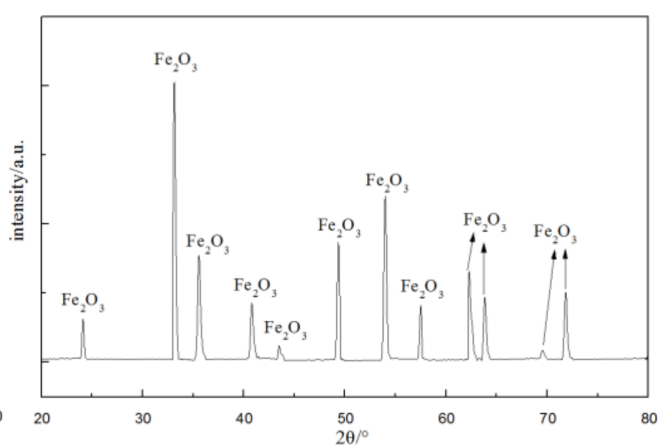

(b)

Figure 3. (a) XRD analysis result of the Super304H sample's surface; (b) XRD analysis result of the HR3C sample' surface. 
Table 3. XRD data for $2 \theta$.

\begin{tabular}{ccc}
\hline Material & Compound & $2 \theta$ \\
\hline \multirow{3}{*}{ Super304H } & $\mathrm{Fe}_{2} \mathrm{O}_{3}$ & $35.592,50.045,74.406$ \\
& $\mathrm{Cr}_{2} \mathrm{O}_{3}$ & $33.307,43.945,53.553$ \\
& $\mathrm{FeCr}_{2} \mathrm{O}_{4}$ & $30.112,37.093,43.088,53.516,57.980,62.612$ \\
\hline \multirow{2}{*}{$\mathrm{HR3C}$} & $\mathrm{Fe}_{2} \mathrm{O}_{3}$ & $24.133,33.169,35.624,40.806,43.518,49.468$, \\
& & $54.030,57.533,62.407,63.938,69.625,71.922$ \\
\hline
\end{tabular}

The oxidation surface morphology of the sample and the elemental composition of marked region were shown in Figures 4 and 5, respectively. Steam oxidised surface of Super304H was irregularly shaped, and cracks appeared among the flakes, as well as some flakes adhered to the fine particles. Besides, the $\mathrm{O}$ content, and Fe content of the fine particles were higher than the flakes and cracks. HR3C steam oxidised surface was covered with spinel protrusions, no flaky delamination, mainly containing $\mathrm{O}$ and Fe elements. Combined with the results of EDS and XRD analysis, the steam oxidation products of Super $304 \mathrm{H}$ sample were mainly composed of $\mathrm{Fe}_{2} \mathrm{O}_{3}, \mathrm{Cr}_{2} \mathrm{O}_{3}$ and $\mathrm{FeCr}_{2} \mathrm{O}_{4}$, while the oxidation of the HR3C sample was only consist of $\mathrm{Fe}_{2} \mathrm{O}_{3}$. It is so inferred that the steam oxidation layer of the Super $304 \mathrm{H}$ occured spalling while the oxidation layer of $\mathrm{HR} 3 \mathrm{C}$ was relatively intact during the service process.

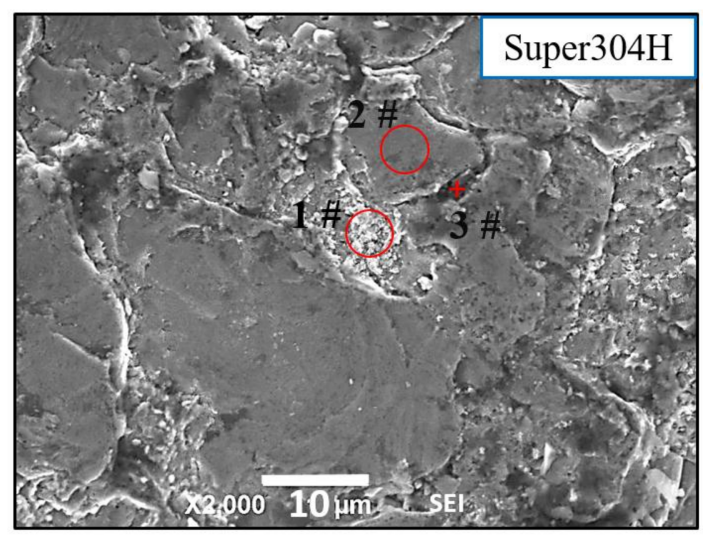

(a)

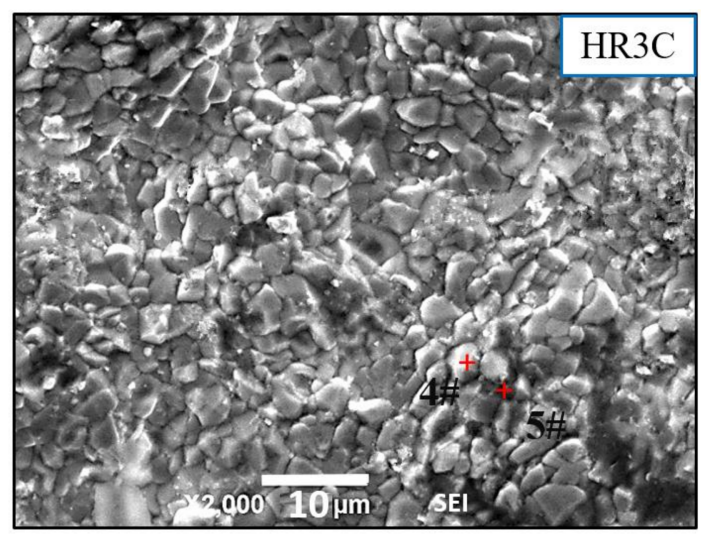

(b)

Figure 4. The SEM surface microstructure: (a) Super304H, (b) HR3C.

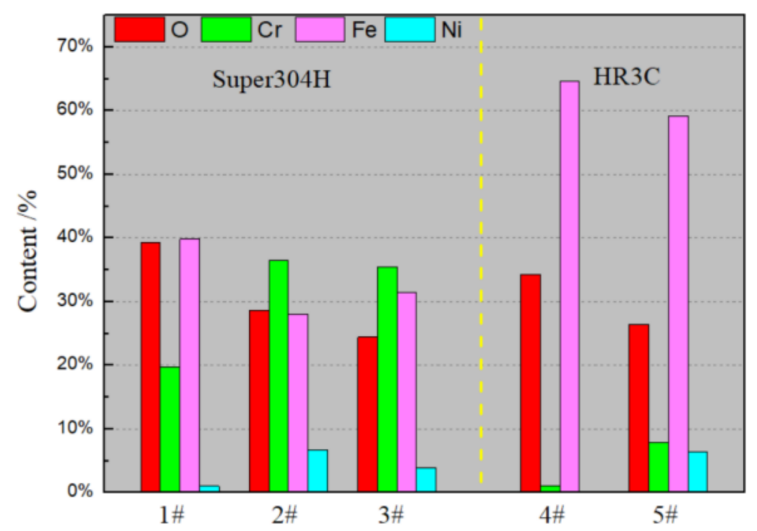

Figure 5. Elementary composition of five identifying spots corresponding to Figure 4.

\subsection{Cross-Section Analysis}

The cross-section microstructure of the oxidised samples Super304H and HR3C are showed in Figure 6 . As the figure showed, the oxidation product was presented in two layers, namely, the outer 
layer mainly contained $\mathrm{Fe}$ and $\mathrm{O}$ and the inner layer mainly contained $\mathrm{Cr}$ and $\mathrm{O}$. Especially in the HR3C sample, the boundary line between the two layers could be distinguished by the naked eye (indicated by the black arrow). Furthermore, the thickness of the oxide scale of Super304 was about 50-70 $\mu \mathrm{m}$, the oxide scale of HR3C sample was relatively continuous and generally the thickness was about $20 \mu \mathrm{m}$. However, the pitting oxidation penetration occurred in some places, and the depth reached $40-50 \mu \mathrm{m}$.
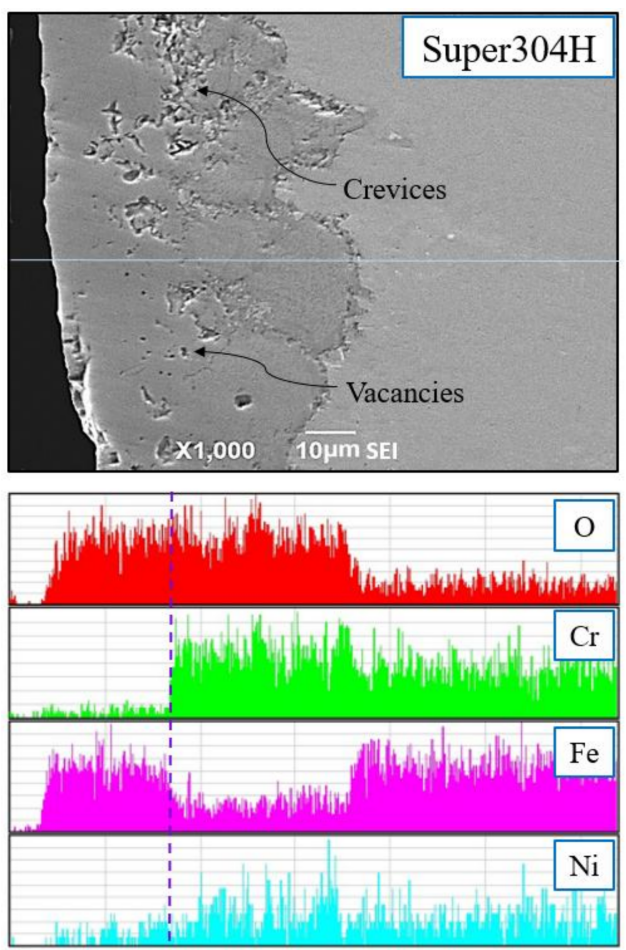

(a)
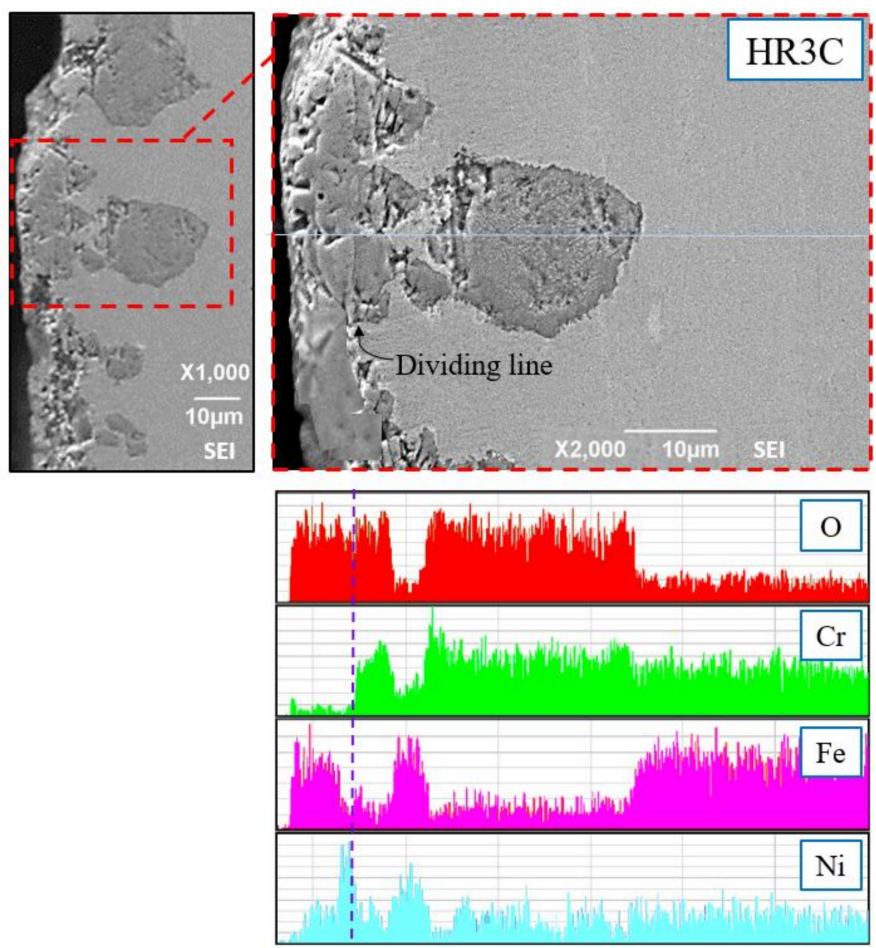

(b)

Figure 6. Cross-sectioned SEM image of: (a) Super304H, (b) HR3C steel oxidised for 17,973 h in a 1000 MW boiler under $26.15 \mathrm{MPa}$ at $605^{\circ} \mathrm{C}$.

Moreover, as shown in Figure 6, regional vacancies appeared near the boundary between the inner and outer layers of the oxide scale for Super304 sample, while the vacancy region of the HR3C sample existed only at the junction of the outer layer of the oxide scale near the surface. There was unoxidized regions in the oxidation inner layer in Figure $6 \mathrm{~b}$, so the oxidation pitting phenomenon in HR3C samples may be caused by narrow gap penetration of $\mathrm{O}$ elements at different positions. In addition, for the Super304 sample, Ni was enriched at the boundary between the steam oxidation layer and the matrix. Nevertheless, for the HR3C sample, Ni was enriched at the boundary between the inner and outer layers of the oxidation layer and in the unoxidized region.

\section{Discussion}

\subsection{Steam Oxidation Mechanism}

According to Ellingham-Richardson diagram [23], the Gibbs free energy $\left(\Delta G^{\theta}\right)$ formed by $\mathrm{Fe}_{2} \mathrm{O}_{3}$ in the alloy was higher than that of $\mathrm{Cr}_{2} \mathrm{O}_{3}$. Therefore, $\mathrm{Cr}_{2} \mathrm{O}_{3}$ preferentially generated on the matrix surface during the oxidation process. The $\mathrm{Cr}_{2} \mathrm{O}_{3}$ generated on Super $304 \mathrm{H}$ and $\mathrm{HR} 3 \mathrm{C}$ surface could resist the continued oxidation to the matrix and prevent the continued formation of $\mathrm{Fe}_{2} \mathrm{O}_{3}$.

The inner layer of oxidation products for Super304H sample was consist of $\mathrm{Cr}_{2} \mathrm{O}_{3}$ and $\mathrm{FeCr}_{2} \mathrm{O}_{4}$, and the chemical formula for forming $\mathrm{FeCr}_{2} \mathrm{O}_{4}$ was as shown in the Equations (1)-(3). The $\mathrm{Cr}$ content 
of Super $304 \mathrm{H}$ was not high, only $18.71 \%$ as well as much lower than $25 \%$, which obtained difficulty to support the formation of a continuous dense $\mathrm{Cr}_{2} \mathrm{O}_{3}$ barrier [24]. Therefore, there were gaps among the $\mathrm{Cr}_{2} \mathrm{O}_{3}$ products, and the $\mathrm{O}$ element could continue to migrate to the substrate through the gaps.

$$
\begin{gathered}
\mathrm{H}_{2} \mathrm{O} \text { (supercritical) }=\mathrm{H}_{2}(\mathrm{~g})+1 / 2 \mathrm{O}_{2}(\mathrm{~g}) \\
4 \mathrm{Cr}(\mathrm{s})+3 \mathrm{O}_{2}(\mathrm{~g})=2 \mathrm{Cr}_{2} \mathrm{O}_{3}(\mathrm{~s}) \\
2 \mathrm{Fe}(\mathrm{s})+\mathrm{O}_{2}(\mathrm{~g})+2 \mathrm{Cr}_{2} \mathrm{O}_{3}(\mathrm{~s})=2 \mathrm{FeCr}_{2} \mathrm{O}_{4}(\mathrm{~s})
\end{gathered}
$$

The Cr content of HR3C was $25.61 \%$, more than $25 \%$ [24], which formed a continuous dense $\mathrm{Cr}_{2} \mathrm{O}_{3}$ barrier to prevent the penetration of $\mathrm{O}$. However, the formation of micro-gaps among the $\mathrm{Cr}_{2} \mathrm{O}_{3}$ was supported by the uneven distribution of $\mathrm{Cr}$, as well as the existence of thermal coefficients of expansion discrepancy between the oxidation scale and matrix. Even if some $\mathrm{O}$ element crossed the oxidation inner layer and invaded the material matrix through the micro-gaps, the abundant $\mathrm{Cr}$ in the matrix would react with $\mathrm{O}$ quickly and formed new $\mathrm{Cr}_{2} \mathrm{O}_{3}$ denser protective layer. This is the reason why the oxidative pitting of the HR3C sample can be observed in Figure 6.

Furthermore, according the work by D.J Young and Pint regarding Cr evaporation [25], the volatiles $\mathrm{CrO}_{3}$ and $\mathrm{CrO}_{2}(\mathrm{OH})_{2}$ formed during the oxidation process as Equations (4) and (5), and depleting the scale in $\mathrm{Cr}$. Higher-alloyed steels have a much better resistance to the formation of Fe-rich oxides but clearly show accelerated depletion of $\mathrm{Cr}$ from the alloy in the presence of water vapor. The accelerated loss of $\mathrm{Cr}$ and the associated accelerated formation of Fe-rich oxide is an acute problem for heat exchangers in power plants. Furthermore, $\mathrm{Cr}$ evaporation in extremely high pressure was the reason why no compounds containing $\mathrm{Cr}$ was observed in $25 \% \mathrm{Cr}$ steel (HR3C), according this work, where activity of $\mathrm{Cr}$ is much higher than in $18 \%$ steel (Super304H). In Super304H steel, some spinal was observed because $\mathrm{Cr}$ activity is lower than in HR3C steel and lower rate of $\mathrm{Cr}$ evaporation was observed. The lack of $\mathrm{Cr}$ in $\mathrm{Cr}$ based phases in the HR3C oxide scale derived from the fact that whole $\mathrm{Cr}$ concentration from the outer layer of the oxide scale evaporated during $17,973 \mathrm{~h}$ of exposure under operating condition.

$$
\begin{gathered}
2 \mathrm{Cr}_{2} \mathrm{O}_{3}(\mathrm{~s})+3 \mathrm{O}_{2}(\mathrm{~g})=4 \mathrm{CrO}_{3}(\mathrm{~g}) \\
2 \mathrm{Cr}_{2} \mathrm{O}_{3}(\mathrm{~s})+3 \mathrm{O}_{2}(\mathrm{~g})+4 \mathrm{H}_{2} \mathrm{O} \text { (supercritical) }=4 \mathrm{CrO}_{2}(\mathrm{OH})_{2}(\mathrm{~g})
\end{gathered}
$$

\subsection{Oxidation Layer Spalling Mechanism}

During the steam oxidation process, the iron ions continuously migrated outward and formed vacancies. The vacancies connected together are the foundation for the crevices. Furthermore, the existence of thermal coefficients of expansion discrepancy between the outer and inner layer cannot be ignored under the real condition, providing the motivation for the crevice formation. During the service of the material, the ambient temperature of the superheater and the reheater fluctuated within a certain range [26]. When the ambient temperature fluctuated periodically, the stress acting on the oxide scale also alternated between the tensile stress and the compressive stress. Since the infiltrated inner layer acted as a continuous layer of the base layer, the stress was mainly concentrated between the inner and outer layers of the oxidation, so that the crevices were enlarged and connected at the junction thereof. As a result, in the high temperature fluctuation environment [27], when the crevices formed by the vacancies and the connection was expanded to a certain extent, the outer oxidation layer spalled off under the coupling of force and heat.

The mechanical strength of the oxidation inner layer determined whether the oxidation outer layer desquamated or not. According to the above discussion, HR3C had a certain strength compared with Super304H due to the higher $\mathrm{Cr}$ content. In addition, HR3C had a higher Ni content which enriched between the inner and outer layers to from a bond to reinforce the connection between the two layers. Therefore, no void was observed in the vicinity of the oxidation inner and outer boundary of HR3C in Figure 6, and no large-area detachment of the oxidation outer layer was observed. As a 
consequence, the oxidation outer layer of Super304H was prone to spalling and that of HR3C was not easy to spalling off.

\section{Conclusions}

In this paper, the steam oxidation behavior of the heat-resistant steels Super $304 \mathrm{H}$ (from superheater) and HR3C (from reheater) with service time of $17,973 \mathrm{~h}$ in a $1000 \mathrm{MW}$ ultra-supercritical boiler were studied, and the following conclusions were obtained:

1. The steam oxidized surface of Super $304 \mathrm{H}$ were mostly $\mathrm{Fe}_{2} \mathrm{O}_{3}, \mathrm{Cr}_{2} \mathrm{O}_{3}$ and $\mathrm{FeCr}_{2} \mathrm{O}_{4}$ while that of HR3C was composed of $\mathrm{Fe}_{2} \mathrm{O}_{3}$, according XRD analysis.

2. As the results of SEM and EDS, the oxidation layer of the Super $304 \mathrm{H}$ sample was thick and continuous while the oxidation layer of the HR3C was thin and unevenly distributed. Furthermore, the oxidation products of the two materials could be divided into two layers, the outer layer enriched in $\mathrm{O}$ element and Fe element, and the inner layer enriched in $\mathrm{O}$ element and $\mathrm{Cr}$ element.

3. The surface of the Super $304 \mathrm{H}$ sample was found to be spalling, and the spalling position located at the interface between the inner and outer oxidation layers. To the opposite, the oxide scale of HR3C was not found to have signs of spalling. The main reasons causing this situation were the low $\mathrm{Cr}$ and $\mathrm{Ni}$ content and the existence of thermal coefficients of expansion discrepancy between the outer and inner layer under fluctuated periodically operating conditions of the boiler.

Author Contributions: Conceptualization, J.L. and Q.Z.; Methodology, J.L. and H.M.; Software, H.M.; Validation, H.M. and Y.W.; Formal Analysis, H.M. and Y.W.; Investigation, J.L., H.M. and Y.W; Resources, J.L. and Q.Z.; Data Curation, H.M. and Y.W.; Writing-Original Draft Preparation, H.M., Y.W. and M.X.; Writing-Review \& Editing, H.M. and Y.W.; Supervision, Y.W. and Q.Z.; Project Administration, Y.W. and Q.Z.; Funding Acquisition, J.L., Y.W. and Q.Z.

Funding: This work was supported by the National Natural Science Foundation of China (No. 51606144) and the Scientific Research Project of Shaanxi Quality and Technical Supervision System (2017KY01).

Acknowledgments: Faithful thanks to Zhiyuan Liang for his extremely professional and helpful suggestions to this paper.

Conflicts of Interest: The authors declare no conflict of interest.

\section{References}

1. Wright, I.G.; Dooley, R.B. A Review of the Oxidation Behaviour of Structural Alloys in Steam. Int. Mater. Rev. 2010, 55, 129-167. [CrossRef]

2. Choi, S.M.; Park, J.S.; Sohn, H.S.; Kim, S.H.; Cho, H.H. Thermal Characteristics of Tube Bundles in Ultra-Supercritical Boilers. Energies 2016, 9, 779. [CrossRef]

3. Viswanathan, R.; Sarver, J.; Tanzosh, J.M. Boiler Materials for Ultra-supercritical Coal Power Plants-stearmside Oxidation. J. Mater. Eng. Perform. 2006, 15, 255-274. [CrossRef]

4. Valicek, J.; Palkova, Z.; Harnicarova, M.; Kusnerova, M.; Lukac, O. Thermal and Performance Analysis of a Gasification Boiler and Its Energy Efficiency Optimization. Energies 2017, 10, 1066. [CrossRef]

5. Abe, F.; Kutsumi, H.; Haruyama, H.; Okubo, H. Improvement of Oxidation Resistance of 9 Mass $\%$ Chromium Steel for Advanced-ultra Supercritical Power Plant Boilers by Pre-oxidation treatment. Corros. Sci. 2017, 114, 1-9. [CrossRef]

6. Gomez, M.A.; Comesana, R.; Alvarez Feijoo, H.P.; Eguia, P. Simulation of the Effect of Water Temperature on Domestic Biomass Boiler Performance. Energies 2012, 5, 1044-1061. [CrossRef]

7. Wang, C.N.; Chou, M.T.; Hsu, H.P.; Wang, J.W.; Selvaraj, S. The Efficiency Improvement by Combining HHO Gas, Coal and Oil in Boiler for Electricity Generation. Energies 2017, 10, 251. [CrossRef]

8. Chen, G.H.; Zhang, Q.; Liu, J.J.; Wang, J.Q.; Yu, X.H.; Hua, J.; Bai, X.L.; Zhang, T.; Zhang, J.H.; Tang, W.M. Microstructures and Mechanical Properties of T92/Super304H Dissimilar Steel Weld Joints After High-temperature Ageing. Mater. Design 2017, 44, 469-475. [CrossRef] 
9. Zhang, Z.; Hu, Z.F.; Tu, H.Y.; Schmauder, S.; Wu, G.X. Microstructure Evolution in HR3C Austenitic Steel During Long-term Creep at 650 degrees C. Mater. Sci. Eng., A 2017, 681, 74-84. [CrossRef]

10. Viitala, H.; Galfi, I.; Taskinen, P. Initial Oxidation Behaviour of Niobium Stabilized TP347H Austenitic Stainless Steel-Effect of Grain Size and Temperature. Mater. Corros. 2017, 66, 851-862. [CrossRef]

11. Zurek, J.; Wessel, E.; Niewolak, L.; Schmitz, F.; Kern, T.U.; Singheiser, L.; Quadakkers, W.J. Anomalous Temperature Dependence of Oxidation Kinetics During Steam Oxidation of Ferritic Steels in the Temperature Range 550-650 degrees C. Corros. Sci. 2004, 46, 2301-2317. [CrossRef]

12. Quadakkers, W.J.; Ennis, P.J.; Zurek, J.; Michalik, M. Steam Oxidation of Ferritic Steels-laboratory Test Kinetic Data. Mater. High Temp. 2005, 22, 47-60. [CrossRef]

13. Wright, I.G.; Dooley, R.V. Morphologies of Oxide Growth and Exfoliation in Superheater and Reheater Yubing of Steam Boiler. Mater. High Temp. 2011, 28, 40-57. [CrossRef]

14. Hansson, A.N.; Korcakova, L.; Hald, J.; Montgomery, M. Long Term Steam Oxidation of TP347HFG in Power Plants. Mater. High Temp. 2005, 22, 263-267. [CrossRef]

15. Liang, Z.Y.; Singh, P.M.; Zhao, Q.X.; Wang, Y.S. High Temperature Oxidation of Newly Developed Alloy 282 in the Flowing-Air and Steam Condition at 900-1100 degrees C. Oxid. Met. 2015, 84, 291-305. [CrossRef]

16. Rosser, J.C.; Bass, M.I.; Cooper, C.; Lant, T.; Brown, P.D.; Connolly, B.J. Steam Oxidation of Super 304H and Shot-peened Super304H. Mater. High Temp. 2012, 29, 95-106. [CrossRef]

17. Yuan, J.Y.; Wu, X.M.; Wang, W.; Zhu, S.L.; Wang, F.H. The Effect of Surface Finish on the Scaling Behavior of Stainless Steel in Steam and Supercritical Water. Oxid. Met. 2013, 79, 541-551. [CrossRef]

18. Yue, Z.W.; Fu, M.; Wang, X.G.; Li, X.G. Effect of Shot Peening on the Oxidation Resistance of TP304H and HR3C Steels in Water Vapor. Oxid. Met. 2012, 77, 17-26. [CrossRef]

19. Iseda, A.; Okada, H.; Semba, H.; Igarashi, M. Long Term Creep Properties and Microstructure of SUPER304H, TP347HFG and HR3C for A-USC Boilers. Energy Met. 2007, 2, 199-206. [CrossRef]

20. Dudziak, M.; Lukaszewicz, M.; Simms, N.J.; Nicholls, J.R. Steam Oxidation of TP347HFG, Super 304H and HR3C-analysis of Significance of Steam Flowrate and Specimen Surface Finish. Corros. Eng. Sci. Techn. 2015, 50, 272-282. [CrossRef]

21. Lukaszewicz, M.; Simms, N.J.; Dudziak, T.; Nicholls, J.R. Effect of Steam Flow Rate and Sample Orientation on Steam Oxidation of Ferritic and Austenitic Steels at 650 and 700 degrees C. Oxid. Met. 2013, 79, 473-483. [CrossRef]

22. Dudziak, T.; Lukaszewicz, M.; Simms, N.J.; Nicholls, J.R. Impact Specimen Geometry on T23 and TP347HFG Steels Behaviour During Steam Oxidation at Harsh Condition. Corros. Eng. Sci. Techn. 2017, 52, 46-53. [CrossRef]

23. Liu, L.L.; Liu, S.; Guo, Q.Q.; Shen, J.; Li, W.B.; Niu, Y. Effects of Cr Addition and a Magnetron Sputtered Film on the Oxidation-Sulfidation Behavior of Fe-xCr-5Si Alloys in $\mathrm{H}_{2}-\mathrm{CO}_{2}-\mathrm{H}_{2} \mathrm{~S}$ Mixture at 800 degrees C. J. Electrochem. Soc. 2017, 164, C269-C275. [CrossRef]

24. Ericsson, T. A Study of the Cr-depleted Surface Layers Formed on Four Cr-Ni Steels During Oxidation in Steam at 600 and 800 degree C. Oxid. Met. 1970, 2, 401-417. [CrossRef]

25. Young, D.J.; Pint, B.A. Chromium Volatilization Rates from $\mathrm{Cr}_{2} \mathrm{O}_{3}$ Scales into Flowing Gases Containing Water Vapor. Oxid. Met. 2006, 66, 137-153. [CrossRef]

26. Yan, W.J.; Ya, Y.Q.; Du, F.; Shao, H.; Zhao, P.T. Spectrometer-Based Line-of-Sight Temperature Measurements during Alkali-Pulverized Coal Combustion in a Power Station Boiler. Energies 2017, 10, 1375. [CrossRef]

27. Zhao, Y.; Men, Y.H.; Han, P. Modeling and Simulation of Complex Fluid Networks in the Flue Gas System of a Boiler. Energies 2017, 10, 1432. [CrossRef]

(C) 2019 by the authors. Licensee MDPI, Basel, Switzerland. This article is an open access article distributed under the terms and conditions of the Creative Commons Attribution (CC BY) license (http://creativecommons.org/licenses/by/4.0/). 